\title{
Studies of the aromatic $\beta$-diketones as extractant of copper ions
}

\author{
Katarzyna Witt ${ }^{1, *}$, and Elzbieta Radzyminska-Lenarcik ${ }^{1}$ \\ ${ }^{1}$ Faculty of Chemical Technology and Engineering, UTP University of Sciences and Technology, Seminaryjna 3, PL-85326 Bydgoszcz, \\ Poland
}

\begin{abstract}
Benzoylacetone $\underline{\mathbf{2}}$, dibenzoylmethane $\underline{\mathbf{3}}$ and acetylacetone $\underline{\mathbf{1}}$ were studied as extractants of copper ions by liquid-liquid partition and spectrophotometric methods. Extraction ability increase in order $\underline{\mathbf{1}}<\underline{\mathbf{2}}<$ ․ The values of $\mathrm{pH}_{1 / 2}$, corresponding to $50 \%$ of the extraction of copper, are equal to $10.75,10.08$ and 9.85 for $\underline{\mathbf{1}}, \underline{\mathbf{2}}, \underline{\mathbf{3}}$, respectively. The extraction process is the most effective when $\underline{\mathbf{3}}$ was used as extractant, the maximum amount of copper ions passed to the organic phase is $50 \%$ and $99 \%$ for $\underline{\mathbf{1}}$ and $\underline{\mathbf{3}}$, respectively. The spectra have shown that in the aqueous and in the organic phase $\beta$-diketone form two chelated complexes $[\mathrm{CuL}]^{+}$and $\left[\mathrm{CuL}_{2}\right]$. Partition ratios $\left(\mathrm{P}_{2}\right)$ of $\left[\mathrm{CuL}_{2}\right]$ complexes have very high values, much higher than $\mathrm{P}_{1}$. That complexes determine the efficiency of extraction process of $\mathrm{Cu}(\mathrm{II})$ ions, what confirm the electron absorption spectra.
\end{abstract}

\section{Introduction}

Hydrometallurgy is concerned with aqueous solutions, and thus metal ions are the species of interest. Extraction of metal ions directly into a water-immiscible oil phase is energetically unfavorable, and this process can only be accomplished by arranging that the metal ion be transferred to the organic phase as a neutral species. Such species can be produced by aqueous complexing or by association with anions whereby, by careful choice of ligand concentration, a neutral species extractable by an organic solvent can be produced [1,2].

Copper is also presented in a number of effluents or waste waters of various nature, being also its elimination a primary target from an environmental point of view, with solvent extraction and membrane technologies gaining an important role in this approach [3].

$\beta$-Diketones are successfully used as extractants in solvent extraction. The most known $\beta$-diketone extractants are the commercial compounds of the LIX group. These include, e.g. LIX 54-100, which is a composition of six $\beta$-diketone isomers: 1-phenyldecane1,3-diones, heptane-8,10-dione and 1,3-diphenylpropane1,3-dione. Ochromowicz et al. [4] and Kyuchoukov et al. [5] conducted extraction of copper(II) from ammoniacal solutions by among others a LIX 54-100. Also other metals, for example nickel, can be separated from ammoniacal media by means of LIX 54 [6]. Authors proved that nickel extraction is very sensitive to equilibrium $\mathrm{pH}$ and the extraction decreases beyond $\mathrm{pH}$ 9.0.

In the literature one can find articles on other commercial $\beta$-diketones used in solvent extraction. For example Weng et al. [7] carried out separation and recovery of copper from ammoniacal chloride solutions by solvent extraction using 1-phenyl-3-heptyl-1,3- propanedione, 1-phenyl-4-ethyl-1,3-octanedione and 1(4'-dodecyl) phenyl-3-tert-butyl-1,3-propanedione in kerosene. The results indicated that the last demonstrated the best selectivity for the separation of copper from nickel and zinc.

In our previous paper [8] we described a liquid-liquid partition and spectrophotometric methods, which were used to examine the process of complexes formation of acetylacetone, 3-butyl-acetylacetone and 3-allylacetylacetone with $\mathrm{Cu}(\mathrm{II})$ ions during extraction process. We proved that the highest efficiency of extraction of copper(II) complexes was observed in the case of 3-allylacetylacetone.

The process of extraction of Th(IV), U(VI) and $\mathrm{Mo}(\mathrm{VI})$ ions was introduced by Monhanty et al. [9]. For separation U(VI) ions a mixture of $10 \%(\mathrm{v} / \mathrm{v})$ LIX 84 and $0.1 \mathrm{M}$ dibenzoylmethane at $\mathrm{pH} 4.2$ and mixture of $10 \%$ LIX 84 and $0.05 \mathrm{M}$ thenoyl-trifluoro-acetone in the $\mathrm{pH}$ range 5.5-7.3 was used. The Mo(VI) ions was extracted from chloride media by $10 \%$ LIX 84 at $\mathrm{pH} 1.5$. It was shown that extraction decreases very rapidly with increase in the concentration of $\mathrm{HCl}$ as compared to that from $\mathrm{H}_{2} \mathrm{SO}_{4}, \mathrm{HNO}_{3}$ and $\mathrm{HClO}_{4}$ acid solutions. Inconsiderable extraction has been observed in case of Th(IV) by LIX 84 or its mixtures.

Virnig et al. [10] synthesed novel sterically hindered $\beta$-diketones and proposed method of their use in the extraction of copper from aqueous ammoniacal solutions containing copper resulting from commercial processes, including leaching of copper from ores, such as sulfidic ores, or concentrates resulting from flotation of such sulfidic ores.

Aromatic diketones, such as benzoylmethane and dibenzoylmethane, are also commonly known as very good complexing agents. This made them also very effective extractant in the separation of metal ions using

\footnotetext{
* Corresponding author: Katarzyna.Witt@utp.edu.pl
} 
solvent extraction. El-Naggar, Abdel-Gawad, and Someda were proposed process of extraction of Co(III) by benzoylacetone from acetateacetic acid solutions [11]. Also Nezhadali et al. investigated competitive metal ion extraction of $\mathrm{Cu}(\mathrm{II}), \mathrm{Ni}(\mathrm{II}), \mathrm{Zn}(\mathrm{II})$ and $\mathrm{Mn}(\mathrm{II})$ ions by benzoylacetone with addition of acetylacetone. The experiments were conducted at $\mathrm{pH} 3-7$. Results shown that in case of $\mathrm{Cu}$ (II) ions both extractants have a similar effect. Copper ions have been also more effectively extracted compared with the other tested cations like $\mathrm{Ni}(\mathrm{II}), \mathrm{Zn}(\mathrm{II})$ and $\mathrm{Mn}(\mathrm{II})$ [12].

Whereas dibenzoylmethane was used as extractant of copper ions by Kondo et al. [13]. They research were mainly concentrated on kinetic studies of the extraction of copper.

The aims of this work were investigated acid-base and extraction properties of two derivatives of $\beta$-diketones:

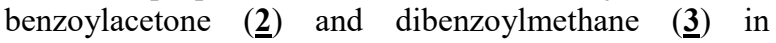
comparison with unsubstituted acetylacetone (1) (Fig. 1). The extraction process was conducted in ammonia solutions at $25^{\circ} \mathrm{C}$. Methylene chloride was used as a solvent.

\section{Experimental}

\subsection{Reagents}

$\beta$-Diketones used for research were commercial compounds (Fig. 1). Acetylacetone $\underline{\mathbf{1}}$ was purchased from Avantor (Gliwice, Poland), dibenzoylacetone $\underline{\mathbf{2}}$ and benzylacetone $\underline{\mathbf{3}}$ were purchased from Sigma Aldrich (Poznan, Poland).

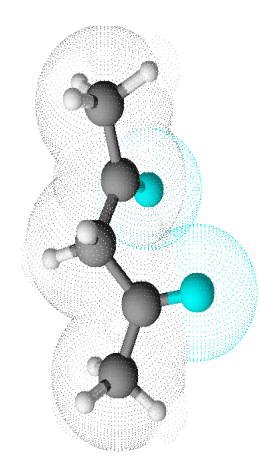

acetylacetone $\mathrm{CH}_{3}-\mathrm{CO}-\mathrm{CH}_{2}-\mathrm{CO}-\mathrm{CH}_{3}$

$\underline{1}$

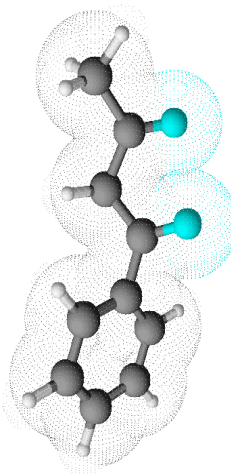
benzoylacetone $\mathrm{CH}_{3}-\mathrm{CO}-\mathrm{CH}_{2}-\mathrm{CO}-$ $\mathrm{C}_{6} \mathrm{H}_{5}$ $\underline{2}$

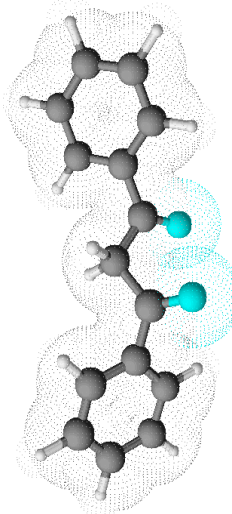

dibenzoylmethane $\mathrm{C}_{6} \mathrm{H}_{5}-\mathrm{CO}-\mathrm{CH}_{2}-\mathrm{CO}-$ $\mathrm{C}_{6} \mathrm{H}_{5}$
Fig. 1. Structure of the studied extrahents.

The potassium and copper(II) nitrates, both of analytical reagent grade (Avantor, Gliwice, Poland) were recrystallized from distilled water. The concentration of potassium nitrate was determined gravimetrically as potassium sulphate. Ammonia buffer was prepared from ammonia and ammonium nitrate (both analytical reagent grade, Avantor, Gliwice, Poland). Carbonate free potassium hydroxide (the titrant, Avantor, Gliwice, Poland) was prepared and standardized against a standard potassium hydrogenphthalate solution. Methylene chloride and methanol (analytical reagent grade, Avantor, Gliwice, Poland) were used as received. The $\mathrm{pH}$-meter was calibrated using commercial buffer solutions (Radiometer, Warsaw, Poland) having a $\mathrm{pH}$ of $7.00 \pm 0.01$ and $9.21 \pm 0.01$. The $\mathrm{pH}$ was also checked against hydrochloric acid according to IUPAC recommendations [14].

\subsection{Equipment}

Potentiometric measurements were carried out using a multifunctional computer-aided pH-meter (PHM 250, Radiometer, Warsaw, Poland) equipped with a glasscalomel combination electrode C 2401-8 (Radiometer, Copenhagen, Denmark). The atomic absorption spectrophotometer 210 VGP (BUCK Scientific, East Norwalk, USA) was used for determination of $\mathrm{Cu}$ (II) concentrations. A Cary 50 (Varian, Melbourne, Victoria, Australia) spectrophotometer was used for recording the absorption spectra of the $\mathrm{Cu}$ (II) complexes in the aqueous and organic phase over the range $400 \mathrm{~nm}-1000 \mathrm{~nm}$.

\subsection{Determination of dissociation constants $(\mathrm{pK}$ )}

The dissociation constants $\left(\mathrm{pK}_{\mathrm{a}}\right)$ of $\beta$-diketones $(\underline{\mathbf{2}}, \underline{\mathbf{3}})$ were determined by potentiometric titration. Measuring cell was thermostated at $25^{\circ} \mathrm{C} \pm 0.5^{\circ} \mathrm{C}$. Two watermethanol solutions were prepared. One contained $\mathrm{KOH}$ (1 $\left.\mathrm{mmol} / \mathrm{dm}^{3}\right)$, chosen $\beta$-diketone, and a proper quantity of potassium nitrate to ensure a constant ionic strength (1 $\left.\mathrm{mol} / \mathrm{dm}^{3}\right)$. Another solution was prepared in a similar manner but without $\beta$-diketone. Measurements were taken for two $\beta$-diketone concentrations $\left(0.06 \mathrm{~mol} / \mathrm{dm}^{3}\right.$ and 0.05 $\mathrm{mol} / \mathrm{dm}^{3}$ ) in the first solution. A $50 \mathrm{~cm}^{3}$ volume of first solution was placed in the measuring cell, and the solution was titrated with standard solution of $5 \mathrm{mmol} / \mathrm{dm}^{3} \mathrm{KOH}$. Then the second solution was titrated in the same way. Three series of measurements were done.

\subsection{Extraction Procedure}

The measurements were run at $25^{\circ} \mathrm{C}$, at a fixed ionic strength $\left(0.5 \mathrm{~mol} / \mathrm{dm}^{3}\right)$ maintained in the aqueous phase with $\mathrm{KNO}_{3}$. A constant $\mathrm{pH}$ was maintained using ammonia buffer $\left(\mathrm{NH}_{3}+\mathrm{NH}_{4} \mathrm{NO}_{3}, 1: 1\right)$. Before an extraction, concentrations of $\mathrm{Cu}(\mathrm{II})$ ions in the aqueous phase were held constant $\left(0.01 \mathrm{~mol} / \mathrm{dm}^{3}\right)$ whereas the ligand (1- $\underline{\mathbf{3}})$ concentrations in organic phase (methylene chloride) were varied (from 0.01 to $0.03 \mathrm{~mol} / \mathrm{dm}^{3}$ ). A volume of $5 \mathrm{~cm}^{3}$ of the aqueous phase was placed in a graduated test tube and an equal volume of a $\beta$-diketone (1- $\underline{\mathbf{3}})$ solution in the organic solvent was added. The test tubes were then shaken for $30 \mathrm{~min}$. The equilibrium was established after a few minutes; however, never longer than $30 \mathrm{~min}$. Afterwards, it was checked if any changes in the phase volumes had occurred, then the phases were separated and the $\mathrm{pH}$ of the aqueous phase was measured. The $\mathrm{Cu}(\mathrm{II})$ concentration in the aqueous phase was determined by atomic absorption spectrophotometry. The 
detection limit of the method was found to be $0.2 \mu \mathrm{g} / \mathrm{dm}^{3}$ and the relative standard deviation was about $6 \%$.

\subsection{Spectrophotomeric examination}

$\mathrm{UV}-\mathrm{Vis}$ spectra of the aqueous and organic phase were recorded in the wavelength range of $400 \mathrm{~nm}$ to $1000 \mathrm{~nm}$. Water solution of $0.5 \mathrm{~mol} / \mathrm{dm}^{3} \mathrm{KNO}_{3}$ was used as reference solution while testing a aqueous phase, whereas the organic phase was tested against methylene chloride. The spectra of the samples were recorded with spectral slits of $1 \mathrm{~nm}$ and with $1 \mathrm{~nm}$ steps using curettes having 1 $\mathrm{cm}$ path lengths.

\section{Results and discussion}

\subsection{Dissociation constants of aromatic $\beta$ - diketones}

Aromatic $\beta$-diketones dissociate according to the following reaction:<smiles>[R]C(=O)/C=C(/[R])[OH+]</smiles>

Dissociation constants $\left(\mathrm{pK}_{\mathrm{a}}\right)$ of investigated ligands $(\underline{\mathbf{2}}$ 3) were determined by potentiometric method using equilibrium constant of the above reaction:

$$
K_{a}=\frac{\left[\mathrm{H}_{3} \mathrm{O}^{+}\right]\left[L^{-}\right]}{[H L]}=\frac{\left[\mathrm{H}_{3} \mathrm{O}^{+}\right]\left(\mathrm{C}_{\mathrm{KOH}}+\left[\mathrm{H}_{3} \mathrm{O}^{+}\right]\right)}{\left(C_{\mathrm{HL}}-C_{\mathrm{KOH}}\right)-\left[\mathrm{H}_{3} \mathrm{O}^{+}\right]}
$$

where $\left[\mathrm{H}_{3} \mathrm{O}^{+}\right], \quad\left[\mathrm{L}^{-}\right]$, and $[\mathrm{HL}]$ are equilibrium concentrations of the hydronium ion, the free ligand ( $\beta$ diketone anion) and its undissociated form, respectively, and $\mathrm{C}_{\mathrm{L}-}, \mathrm{C}_{\mathrm{KOH}}$ are analytical concentrations of the ligand, $\mathrm{HL}$ and $\mathrm{KOH}$ in aqueous solution, respectively.

The values of determined dissociation constants are summarized in Table 1.

Lower values of $\mathrm{pK}_{\mathrm{a}}$ provide stronger acid properties of molecules. $\mathrm{pK}_{\mathrm{a}}$ value of $\underline{\mathbf{2}}$ indicate that compound have slightly lower value than $\underline{\mathbf{1}}$ and $\underline{\mathbf{3}}$ (Table 1). On the other hand dibenzoylmethane is as strong basis as acetylacetone.
Table 1. The dissociation constants $\mathrm{pK}_{\mathrm{a}}$ of investigated $\beta$ diketone derivatives in aqueous-methanol (1:1) solution $\left(\mathrm{I}=1 \mathrm{~mol} / \mathrm{dm}^{3} \mathrm{KNO}_{3}\right)$ at $25^{\circ} \mathrm{C}$.

\begin{tabular}{|c|c|c|}
\hline $\boldsymbol{\beta}$-diketone & $\mathbf{p K}_{\mathbf{a}}$ & ref. \\
\hline $\begin{array}{c}\text { acetylacetone } \\
\mathbf{1}\end{array}$ & 9.65 & {$[15]$} \\
\hline$\underline{\mathbf{2}}$ & 9.61 & \\
\hline $\begin{array}{c}\text { benzoylacetone } \\
\text { [ibenzoylmethane work] } \\
\underline{\mathbf{3}}\end{array}$ & 9.65 & \\
\hline
\end{tabular}

The percentage extractions of the test metal ions in the test systems were calculated for each measured $\mathrm{pH}$ of the aqueous phase using Formula (3):

$$
E \%=\frac{C_{C u}^{0}-C_{C u}}{C_{C u}} \cdot 100 \%
$$

where: $\mathrm{C}^{0} \mathrm{Cu}$ and $\mathrm{C}_{\mathrm{Cu}}$ denote analytical $\mathrm{Cu}$ (II) concentrations in the aqueous phase before and after attaining a partition equilibrium, respectively.

Changes in the percentage extraction vs. $\mathrm{pH}$ of the aqueous phase is presented in the Figure 2.

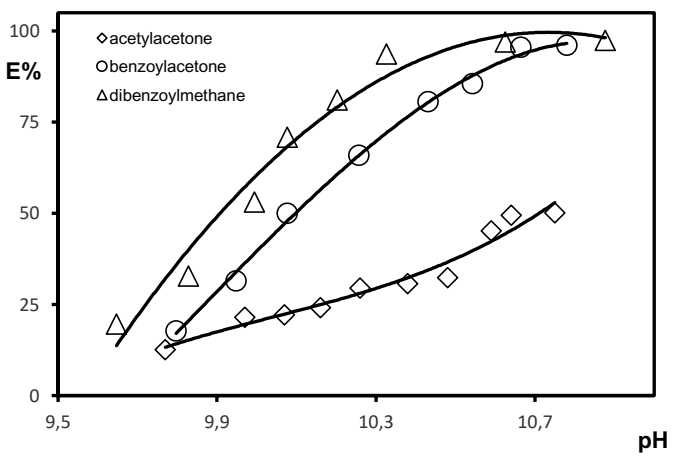

Fig. 2 Percentage extraction vs. pH for $\mathrm{Cu}$ (II) complexes with acac $\diamond$, benzoylacetone $\circ$, dibenzoylmethane $\Delta$ in watermethylene chloride phase systems.

$\beta$-Diketones containing the aromatic ring in the molecule $(\underline{\mathbf{2}}$ and $\underline{\mathbf{3}})$ are more effective extractants than acac ( $\underline{\mathbf{1}})$. The extraction process is the most effective when $\mathbf{3}$ was used as extractant, the maximum amount of copper ions passed to the organic phase is $50 \%$ and $99 \%$ for $\underline{\mathbf{1}}$ and $\underline{\mathbf{3}}$, respectively; although its $\mathrm{pK}_{\mathrm{a}}$ values are the same. Differences in the efficiency of the extraction process have impact on the ability to form complexes. $\beta$ Diketones form chelate complexes with $\mathrm{Cu}(\mathrm{II})$ ions according to equation (4):<smiles>[R]C(=O)CC([R])=O</smiles> 
The logarithms of the reaction equilibrium constant (4) for the copper complexes $\left(\beta_{n}\right)$ with $\underline{\mathbf{1}}, \underline{\mathbf{2}}$ and $\underline{\mathbf{3}}$ are $11.85,12.05$ and 12.98 respectively [16]. The insertion of the aromatic ring into the acetylacetone molecule increases the complexion properties of that extractants.

For $\underline{\mathbf{1}}, \underline{\mathbf{2}}, \underline{\mathbf{3}}$ the values of $\mathrm{pH}_{1 / 2}$, corresponding to $50 \%$ of the extraction of copper, are equal to $10.75,10.08$ and 9.85 , respectively. This ability to form the complexes also increases their susceptibility to extraction to the organic phase. This is evidenced by the absorption spectra of both phases, recorded after the fix a equilibrium of distribution of the organic phase/aqueous phase, as shown in Figures 3 and 4.

A.

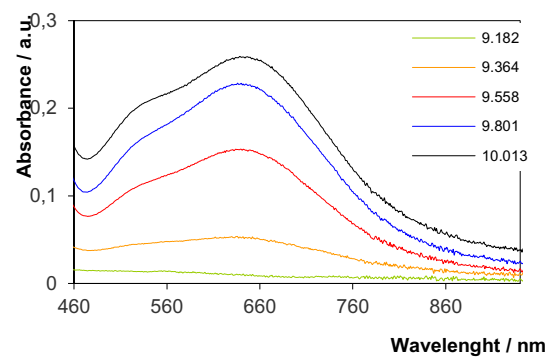

B.

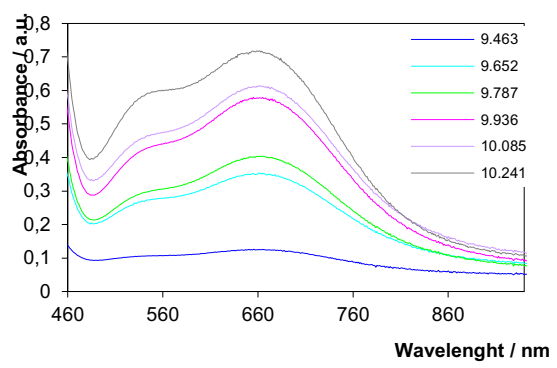

C.

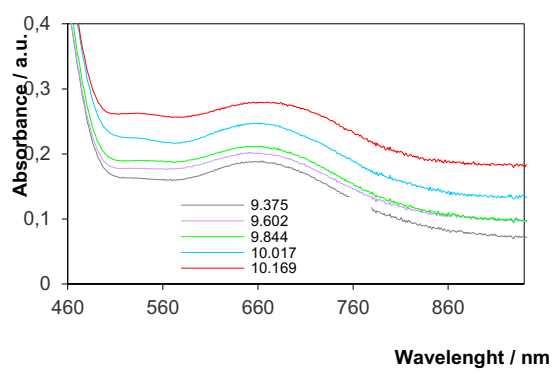

Fig. 3 Absorption spectra of organic phase after extraction of the $\mathrm{Cu}$ (II) complexes with A. acetylacetone, B. benzoyl-acetone, C. dibenzoylmethane in methylene chloride together with the corresponding $\mathrm{pH}$ of the aqueous phase.

To the organic phase in the extraction process (Fig. 3) pass the green copper complexes. Upon raising the ligand concentration, absorption maxima become slightly displaced towards longer wavelengths. The absorption spectra reveal both octahedral (absorption max. around $520 \mathrm{~nm}$ ) and tetrahedral $(660 \mathrm{~nm})$ complexes. The tetrahedral complexes appear at the higher ligand concentrations in the aqueous and organic phases.
A.

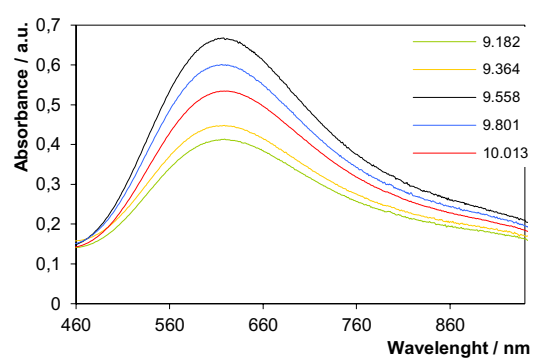

B.

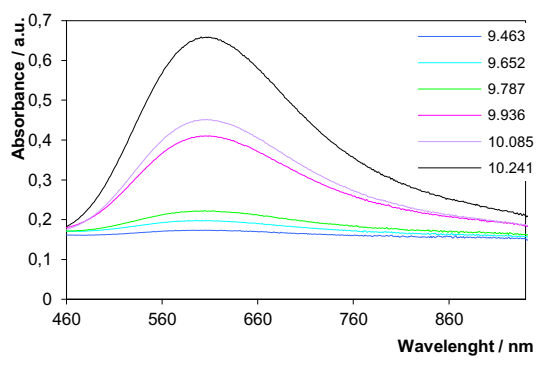

C.

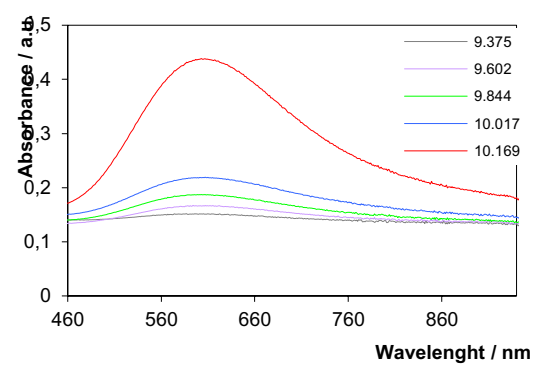

Fig. 4 Absorption spectra of aqueous phase after extraction of the $\mathrm{Cu}$ (II) complexes with A. acetylacetone, B. benzoyl-acetone, C. dibenzoylmethane depending on various $\mathrm{pH}$.

In aqueous phase the $\mathrm{Cu}(\mathrm{II})$ complexes with $\beta$ diketones are blue. Copper complexes with $\underline{\mathbf{2}}$ and $\underline{\mathbf{3}}$ are being created in higher values of $\mathrm{pH}$ of water phase (Fig. 4), which is advantageous in case of copper recovery after leaching by ammonia.

The spectra have shown that in both the aqueous and organic phases $\beta$-diketone form two chelated complexes $[\mathrm{CuL}]^{+}$and $\left[\mathrm{CuL}_{2}\right]$. The first of them can contain two molecules of water in coordination sphere $\left[\mathrm{CuL}\left(\mathrm{H}_{2} \mathrm{O}\right)_{2}\right]^{+}$. The second one is completely anhydrous.

Their partition ratios $\left(P_{n}\right)$ were calculated from formula (5):

$$
\frac{\left[L^{-}\right]^{n}}{E \% / 100}=\frac{\sum_{n=0}^{n=N} \beta_{n}\left[L^{-}\right]^{n}}{P_{n} \beta_{n}}
$$

and summarized in the Table 2.

Table 2. Partition ratios of studied $\beta$-diketones

\begin{tabular}{|c|c|c|}
\hline $\boldsymbol{\beta}$-diketone & $\mathbf{P}_{\mathbf{1}}$ & $\mathbf{P}_{\mathbf{2}}$ \\
\hline $\begin{array}{c}\text { acetylacetone } \\
\underline{\mathbf{1}}\end{array}$ & $7.2 * 10^{4}$ & $4.9 * 10^{7}$ \\
\hline $\begin{array}{c}\text { benzoylacetone } \\
\underline{\mathbf{2}}\end{array}$ & $1.8^{*} 10^{5}$ & $5.6 * 10^{9}$ \\
\hline $\begin{array}{c}\text { dibenzoylmethane } \\
\underline{\mathbf{3}}\end{array}$ & $2.5^{*} 10^{6}$ & $8.3 * 10^{9}$ \\
\hline
\end{tabular}

\footnotetext{
* Corresponding author: Katarzyna.Witt $@$,utp.edu.pl
} 
The values of the partition ratios of the investigated complexes separated between the aqueous and organic phases (methylene chloride) for the studied $\beta$-diketones increase grow in a order $\underline{\mathbf{1}}>\underline{\mathbf{2}}>\underline{\mathbf{3}}$. The values of the partition ratios of the second complexes are at least three orders of magnitude higher than the first one $\left(\mathrm{P}_{2}>>\mathrm{P}_{1}\right)$. Thus, the extraction process is determined by the possibility of forming a second complexes, which takes place at higher $\mathrm{pH}$ values of the aqueous phase. It is preferable to use aromatic $\beta$-diketones as copper extractants from solutions after leaching of ores or waste using ammonia or basis.

\section{Conclusion}

The studied $\beta$-diketones have all qualities to regard them as selective extractants of $\mathrm{Cu}$ (II) ions. It depends on the plasticity of the copper ions coordination sphere, which can easily change shape and adjust to the geometric imposed by $\beta$-diketone. As a result of this interaction a stable copper chelate complexes are formed. In the aqueous and in the organic phase $\beta$-diketone form two chelated complexes $[\mathrm{CuL}]+$ and $[\mathrm{CuL} 2]$. The values of extraction percentage are the highest for dibenzoylmethane. The maximum amount of copper ions passed to the organic phase is $50 \%$ and $99 \%$ for 1 and 3 , respectively and extraction ability increase in order $1<2$ $<3$.

The new developments presented above were carried out within the 2007-2013 Innovative Economy Operational Programme, Sub-action 1.3.2., Support of the protection of industrial property generated by scientific entities as result of R\&D works within project no. UDA-POIG.01.03.02-04-077/12-01, financed by the European Regional Development Fund (ERDF) (85\% of co-financing) and from a designated subsidy (15\% of cofinancing).

\section{References}

1. J. Aromaa, L. Rintala, M. Kahari, O. Forsen, Physicochem. Probl. Miner. Process. 51(1), 269 (2015)

2. K. Ochromowicz, T. Chmielewski, Physicochem. Probl. Miner. Process. 46, 207 (2011)

3. T. Chmielewski Physicochem. Probl. Miner. Process. 51(1), 335 (2015)

4. K. Ochromowicz, M. Jeziorek, K. Wejman, Physicochem. Probl. Miner. Process. 50(1), 327 (2014)

5. G. Kyuchoukov, M.B. Bogacki, J. Szymanowski, Ind. Eng. Chem. Res. 37(10), 4084 (1998)

6. F.J Alguacil, A Cobo, Hydrometallurgy 48, 291 (1998)

7. F. Weng, Ch. Qiyuan, H. Huiping, N. Chunlin, Z. Qinqin.. Sep. Purif. Technol. 80(1), 52 (2011)

8. E. Radzyminska-Lenarcik, K. Witt, Sep. Sci. Technol., DOI: 10.1080/01496395.2017.1329838 (2017)

9. R.N. Mohanty, S. Singh, V. K. Chakravortty, C. Dash, J. Radioanal. Nucl. Chem. 132(2), 359 (1989)

10. M.J. Virnig, G.A. Kordosky, S.I. Kang, K.V. Martin, P.L. Mattison, US 6107523 A (1997)

11. H.A. El-Naggar, A.S. Abdel-Gawad,. H.H. Someda, J. Radioanal. Nucl. Chem. Lett. 128, 233 (1988)

12. A. Nezhadali, A. Sadeghi, M. Roigar, Arab. J. Chem. 8(2), 164 (2015)

13. K. Kondo, T. Tsuneyuki, K. Hiramatsu, F. Nakashio, Sep. Sci. Technol., 25(11-12), 1213 (1990)

14. A. Braibanti, G. Ostacoli, P. Paoletti, L.D. Pettit, S. Sammartano, Pure Appl. Chem. 59, 1721 (1987)

15 K. Witt, E. Radzyminska-Lenarcik, W. Urbaniak, Sep. Sci. Technol. 51(15-16), 2620 (2016)

16. L.G. Van Uitert, W.C. Fernelius, B.E. Douglas, J. Am. Chem. Soc. 75, 457 (1953) 